\title{
PENGEMBANGAN MEDIA PEMBELAJARAN BERBASIS TEKNOLOGI INFORMASI
}

\author{
Oleh: \\ Ali Muhson ${ }^{1}$
}

\begin{abstract}
Abstrak
Media pembelajaran dapat merupakan wahana penyalur pesan dan informasi belajar. Media pembelajaran yang dirancang secara baik akan sangat membantu peserta didik dalam mencerna dan memahami materi pelajaran. Di era globalisasi dan informasi ini, perkembangan media pembelajaran juga semakin maju. Penggunaan Teknologi Informasi (TI) sebagai media pembelajaran sudah merupakan suatu tuntutan. Walaupun perancangan media berbasis TI memerlukan keahlian khusus, bukan berarti media tersebut dihindari dan ditinggalkan. Media pembelajaran berbasis TI dapat berupa internet, intranet, mobile phone, dan CD Room/Flash Disk. Adapun komponen utamanya meliputi Learning Management System (LMS), dan Learning Content (LC).
\end{abstract}

Kata kunci: media pembelajaran, teknologi informasi

\section{A. Pendahuluan}

Pendidikan adalah usaha sadar dan sistematis, yang dilakukan orang-orang yang diserahi tanggung jawab untuk mempengaruhi peserta didik agar mempunyai sifat dan tabiat sesuai dengan cita-cita pendidikan (Achmad Munib, 2004). Oleh karena itu pendidikan diharapkan benar-benar diarahkan untuk menjadikan peserta didik mampu mencapai proses pendewasaan dan kemandirian.

Kemajuan ilmu pengetahuan dan teknologi memiliki pengaruh yang sangat besar dalam berbagai bidang kehidupan manusia. Pendidikan sebagai salah satu bagian yang tidak terpisahkan dari proses pendewasaan manusia tentu di satu sisi memiliki andil yang besar bagi pengembangan ilmu pengetahuan dan teknologi tersebut, namun di sisi lain pendidikan juga perlu memanfaatkan kemajuan ilmu pengetahuan dan teknologi agar mampu mencapai tujuannya secara efektif dan efisien.

Kemajuan ilmu pengetahuan dan teknologi telah berpengaruh terhadap penggunaan alat-alat bantu mengajar di sekolah-sekolah dan lembaga-lembaga pendidikan lainnya. Dewasa ini pembelajaran di sekolah mulai disesuaikan dengan perkembangan teknologi informasi, sehingga terjadi perubahan dan pergeseran paradigma pendidikan (Hujair, 2009). Hal ini mengindikasikan bahwa penggunaan teknologi informasi dalam proses pembelajaran di kelas, sudah menjadi suatu kebutuhan sekaligus tuntutan di era global ini.

Guna meningkatkan efektivitas dan efisiensi pembelajaran, perlu dikembangkan berbagai model pembelajaran yang kreatif dan inovatif. Hal ini perlu dilakukan agar proses pembelajaran tidak terkesan kurang menarik, monoton dan membosankan sehingga akan menghambat terjadinya transfer of knowledge. Oleh karena itu peran media dalam proses pembelajaran menjadi penting karena akan menjadikan proses pembelajaran tersebut menjadi lebih bervariasi dan tidak membosankan.

Pada hakikatnya proses pembelajaran merupakan proses komunikasi atau penyampaian pesan dari pengantar ke penerima. Pesan berupa materi pelajaran yang

\footnotetext{
${ }^{1}$ Staf Pengajar Jurusan Pendidikan Ekonomi - Universitas Negeri Yogyakarta
} 
dituangkan ke dalam simbol-simbol komunikasi baik verbal (kata-kata dan tulisan) maupun nonverbal. Pesan inilah yang akan ditangkap oleh peserta didik sebagai sebuah pengetahuan, keterampilan maupun nilai-nilai yang dapat digunakan dalam kehidupan sehari-hari. Agar pesan tersebut tersampaikan secara efektif tentu membutuhkan sarana atau media yang memadai.

Dalam kenyataannya retensi siswa atau daya tangkap siswa sangat dipengaruhi oleh model aktivitas belajar yang dilakukan guru. Siswa hanya dapat menyerap 5\% bahan pembelajaran apabila aktivitas ceramah dilakukan oleh guru dalam membelajarkan siswa. Sedangkan apabila aktivitas belajar dilakukan dengan teman sebaya, daya retensi siswa mencapai $90 \%$.

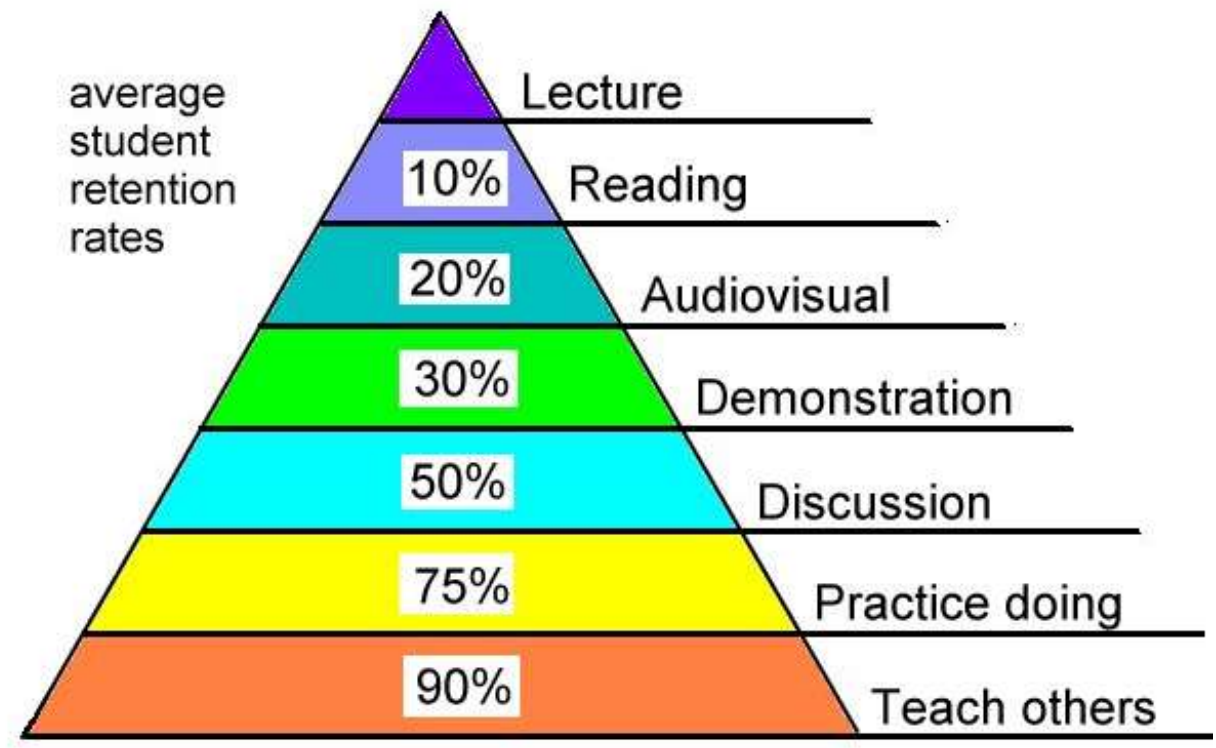

Gambar 1. Piramida Pembelajaran

Penelitian Eyler dan Giles (dalam Widharyanto, 2003) membuktikan bahwa keefektifan pembelajaran dipengaruhi oleh media yang digunakan guru. Mereka menemukan bahwa model pembelajaran yang letaknya paling atas dalam kerucut, yakni pembelajaran yang hanya melibatkan symbol-simbol verbal melalui sajian teks adalah pembelajaran yang menghasilkan tingkat abstraksi paling tinggi. Pembelajaran yang paling efektif adalah pembelajaran yang berada pada dasar kerucut, yakni terlibat langsung dengan pengalamanpengalaman belajar yang bertujuan. Tingkat abstraksi pada model pembelajaran ini sangat rendah sehingga memudahkan siswa dalam menyerap pengetahuan dan keterampilan baru.

\section{B. Pengertian Media Pembelajaran}

Menurut Depdiknas (2003) istilah media berasal dari bahasa Latin yang merupakan bentuk jamak dari "medium" yang secara harafiah berarti perantara atau pengantar. Makna umumnya adalah segala sesuatu yang dapat menyalurkan informasi dari sumber informasi kepada penerima informasi. Proses belajar mengajar pada dasarnya juga merupakan proses komunikasi, sehingga media yang digunakan dalam pembelajaran disebut media pembelajaran. Media pembelajaran merupakan bagian dari sumber belajar yang merupakan kombinasi antara perangkat lunak (bahan belajar) dan perangkat keras (alat belajar).

Association for Education and Communication Technology (AECT), mengartikan kata media sebagai segala bentuk dan saluran yang dipergunakan untuk proses informasi. National Education Association (NEA) mendefinisikan media sebagai segala benda yang dapat dimanipulasikan, dilihat, didengar, dibaca atau dibicarakan beserta instrumen yang 
dipergunakan untuk kegiatan tersebut. Sedangkan HEINICH, dkk (1982) mengartikan istilah media sebagai "the term refer to anything that carries information between a source and a receiver".

Sementara, Marshall McLuhan (dalam Oemar Hamalik, 2003: 201) berpendapat bahwa media adalah suatu ekstensi manusia yang memungkinkannya mempengaruhi orang lain yang tidak mengadakan kontak langsung dengan dia. Sesuai dengan rumusan ini, media komunikasi mencakup surat-surat, televisi, film dan telepon, bahwa jalan raya dan jalan kereta api merupakan media yang memungkinkan seseorang berkomunikasi dengan orang lain.

Lebih lanjut Oemar Hamalik membedakan pengertian media menjadi dua yaitu dalam arti sempit dan dalam arti luas. Dalam arti sempit, media pengajaran hanya meliputi media yang dapat digunakan secara efektif dalam proses pengajaran yang terencana, sedangkan dalam artian luas, media tidak hanya meliputi media komunikasi elektronik yang kompleks, tetapi juga mencakup alat-alat sederhana, seperti slide, fotografi, diagram, dan bagan buatan guru, objek-objek nyata, serta kunjungan ke luar sekolah. Sejalan dengan pandangan itu, guru-guru pun dianggap sebagai media penyajian, di samping radio dan televisi karena samasama membutuhkan dan menggunakan banyak waktu untuk menyampaikan informasi kepada siswa.

Romiszowski (dalam Oemar Hamalik, 2003: 201) merumuskan media pengajaran "....as the carries of massages, from some transmitting source (which may be a human being or an intimate object), to the receiver of the massages (which is our case is the learner). Adapun Djamarah dan Aswan (2002: 136) mendefinisikan media sebagai alat bantu apa saja yang dapat dijadikan sebagai wahana penyalur informasi belajar atau penyalur pesan guna mencapai tujuan pembelajaran. Dalam konteks media sebagai sumber belajar, maka secara luas media dapat diartikan dengan manusia, benda, ataupun peristiwa yang memungkinkan peserta didik memperoleh pengetahuan dan ketrampilan.

Pada hakikatnya berbagai batasan yang dikemukakan di atas mengandung pengertian dasar yang sama. Dalam berkomunikasi kita membutuhkan media atau sarana. Secara umum makna media adalah apa saja yang dapat menyalurkan informasi dari sumber Informasi ke penerima informasi. Jadi media pembelajaran merupakan "perangkat lunak" (Software) yang berupa pesan atau informasi pendidikan yang disajikan dengan memakai suatu peralatan bantu (Hardware) agar pesan/informasi tersebut dapat sampai kepada mahasiswa. Di sini jelas bahwa media berbeda dengan peralatan tetapi keduanya merupakan unsur-unsur yang saling terkait satu sama lain dalam usaha menyampaikan pesan/informasi pendidikan kepada mahasiswa. Dengan demikian dapat disimpulkan bahwa (a) media merupakan wadah dari pesan yang oleh sumber atau penyalurnya ingin diteruskan kepada sasaran atau penerima pesan tersebut, dan (b) bahwa materi yang ingin disampaikan adalah pesan pembelajaran, dan bahwa tujuan yang ingin dicapai adalah terjadinya proses belajar.

\section{Manfaat Media Pembelajaran}

Setiap materi pembelajaran mempunyai tingkat kesukaran yang bervariasi. Pada satu sisi ada bahan pembelajaran yang tidak memerlukan media pembelajaran, tetapi di sisi lain ada bahan pembelajaran yang memerlukan media pembelajaran. Materi pembelajaran yang mempunyai tingkat kesukaran tinggi tentu sukar dipahami oleh siswa, apalagi oleh siswa yang kurang menyukai materi pembelajaran yang disampaikan.

Keberadaan media pembelajaran sebagai alat bantu dalam proses pembelajaran merupakan suatu kenyataan yang tidak bisa dipungkiri. Guru sebagai penyampai pesan memiliki kepentingan yang besar untuk memudahkan tugasnya dalam menyampaikan pesan pesan atau materi pembelajaran kepada peserta didik. Guru juga menyadari bahwa tanpa media, materi pembelajaran akan sulit untuk dapat dicerna dan dipahami oleh siswa, apalagi 
bila materi pembelajaran yang harus disampaikan tergolong rumit dan kompleks. Untuk itu penggunaan media mutlak harus dilakukan agar materi dapat sampai ke peserta didik secara efektif dan efisien.

Secara umum, manfaat media dalam proses pembelajaran adalah memperlancar interaksi antara guru dan siswa sehingga kegiatan pembelajaran akan lebih efektif dan efisien. Tetapi secara khusus ada beberapa manfaat media yang lebih rinci. Kemp dan Dayton (dalam Depdiknas, 2003) mengidentifikasikan beberapa manfaat media dalam pembelajaran yaitu :

1. Penyampaian materi pelajaran dapat diseragamkan.

2. Proses pembelajaran menjadi lebih jelas dan menarik

3. Proses pembelajaran menjadi lebih interaktif

4. Efisiensi dalam waktu dan tenaga

5. Meningkatkan kualitas hasil belajar siswa

6. Media memungkinkan proses belajar dapat dilakukan di mana saja dan kapan saja

7. Media dapat menumbuhkan sikap positif siswa terhadap materi dan proses belajar

8. Mengubah peran guru ke arah yang lebih positif dan produktif.

Selain beberapa manfaat media seperti yang dikemukakan di atas, masih terdapat beberapa manfaat praktis. Manfaat praktis media pembelajaran tersebut adalah :

1. Media dapat membuat materi pelajaran yang abstrak menjadi lebih konkret

2. Media juga dapat mengatasi kendala keterbatasan ruang dan waktu

3. Media dapat membantu mengatasi keterbatasan indera manusia.

4. Media dapat menyajikan objek pelajaran berupa benda atau peristiwa langka dan berbahaya ke dalam kelas.

5. Informasi pelajaran yang disajikan dengan media yang tepat akan memberikan kesan mendalam dan lebih lama tersimpan pada diri siswa.

Berdasarkan beberapa pendapat di atas dapat disimpulkan bahwa secara praktis media pembelajaran memiliki beberapa manfaat, antara lain:

1. Mengkonkretkan konsep-konsep yang bersifat abstrak, sehingga dapat mengurangi verbalisme. Misalnya dengan menggunakan gambar, skema, grafik, model, dan sebagainya.

2. Membangkitkan motivasi, sehingga dapat memperbesar perhatian individual siswa untuk seluruh anggota kelompok belajar sebab jalannya pelajaran tidak membosankan dan tidak monoton.

3. Memfungsikan seluruh indera siswa, sehingga kelemahan dalam salah satu indera (misal: mata atau telinga) dapat diimbangi dengan kekuatan indera lainnya.

4. Mendekatkan dunia teori/konsep dengan realita yang sukar diperoleh dengan cara-cara lain selain menggunakan media pembelajaran. Misalnya untuk memberikan pengetahuan tentang pola bumi, anak tidak mungkin memperoleh pengalaman secara langsung. Maka dibuatlah globe sebagai model dari bola bumi. Demikian juga benda-benda lain yang terlalu besar atau terlalu kecil, gejala-gejala yang gerakannya terlalu cepat atau terlalu lambat, gejala-gejala/objek yang berbahaya maupun sukar didapat, hal-hal yang terlalu kompleks dan sebagainya, semuanya dapat diperjelas menggunakan media pembelajaran.

5. Meningkatkan kemungkinan terjadinya interaksi langsung antar siswa dengan lingkungannya. Misalnya dengan menggunakan rekaman, eksperimen, karyawisata, dan sebagainya.

6. Memberikan uniformitas atau keseragaman dalam pengamatan, sebab daya tangkap setiap siswa akan berbeda-beda tergantung dari pengalaman serta intelegensi masing-masing siswa. Misalnya persepsi tentang gajah, dapat diperoleh uniformitas dalam pengamatan kalau binatang itu diamati langsung atau tiruannya saja dibawa ke depan kelas. 
7. Menyajikan informasi belajar secara konsisten dan dapat diulang maupun disimpan menurut kebutuhan. Misalnya berupa rekaman, film, slide, gambar, foto, modul, dan sebagainya.

\section{Jenis-jenis Media}

Berdasarkan kategori media, Paul dan David (1999) melalui Rishe (2007) berpendapat bahwa ada enam kategori, yaitu media yang tidak diproyeksikan, media yang diproyeksikan, media audio, media film dan video, multimedia, dan media berbasis komunikasi. Sementara, menurut Schramm mengkategorikan media dari dua segi: dari segi kompleksitas dan besarnya biaya dan menurut kemampuan daya liputannya. Briggs mengidentifikasikan tiga belas macam media pembelajaran yaitu objek, model, suara langsung, rekaman audio, media cetak, pembelajaran terprogram, papan tulis, media transparansi, film rangkai, film bingkai, film televise, dan film gambar. Gagne menyebutkan tujuh macam pengelompokkan media, yaitu benda untuk didemostrasikan, komunikasi lisan, media cetak, gambar diam, gambar gerak, film bersuara, dan mesin belajar. Menurut Edling, ada enam macam media pembelajaran yaitu kodifikasi subjektif visual, dan kodifikasi objektif audio, kodifikasi subjektif audio, dan kodifikasi objektif visual, pengalaman langsung dengan orang, dan pengalaman langsung dengan benda-benda. Soeparno (1988), berpendapat bahwa klasifikasi media dilakukan dengan menggunakan tiga unsure berdasarkan karakteristiknya, berdasarkan dimensi presentasinya, dan berdasarkan pemakaiannya.

Bretz (dalam Hujair., 2009) mengidentifikasi ciri utama dari media menjadi tiga unsur pokok, yaitu suara, visual, dan gerak. Visual dibedakan menjadi tiga yaitu gambar, garis, dan simbol yang merupakan suatu kontinum dari bentuk yang dapat ditangkap dengan indera penglihatan. Di samping itu, Bretz juga membedakan antara media siar (telecommunication) dan media rekam (recording) sehingga terdapat delapan klasifikasi media: (1) media audio visual gerak, (2) media audio visual diam, (3) media audio visual semi gerak, (3) media visual gerak, (5) media visual diam, (6) media semi gerak, (7) media audio, dan (8) media cetak.

Dengan menggunakan media pembelajaran secara tepat dan bervariasi dengan pengalaman suara (audio), penglihatan (visual), dan pengalaman gerakan dapat diatasi sikap pasif peserta didik dalam pembelajaran. Contoh dari masing-masing media tersebut di atas tampak pada Tabel 1.

Tabel 1. Jenis-Jenis Media Menurut Bretz

\begin{tabular}{|c|c|c|c|c|c|c|}
\hline Media Transmisi & 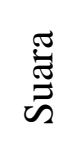 & 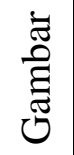 & 悉 & $\begin{array}{l}\overline{0} \\
\text { है } \\
\text { in }\end{array}$ & 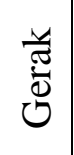 & $\begin{array}{c}\text { Media } \\
\text { Rekaman }\end{array}$ \\
\hline \multicolumn{7}{|c|}{ Audio Visual Gerak } \\
\hline & $\mathrm{X}$ & $\mathrm{X}$ & $\mathrm{X}$ & $\mathrm{X}$ & $\mathrm{X}$ & Film/Suara \\
\hline \multirow[t]{2}{*}{ Televisi } & $\mathrm{X}$ & $\mathrm{X}$ & $\mathrm{X}$ & $\mathrm{X}$ & $\mathrm{X}$ & $\begin{array}{l}\text { Pita Video } \\
\text { Film TV }\end{array}$ \\
\hline & $\mathrm{X}$ & $\mathrm{X}$ & $\mathrm{X}$ & $\mathrm{X}$ & $\mathrm{X}$ & Holografi \\
\hline Gambar/Suara & $\mathrm{X}$ & $\mathrm{X}$ & $\mathrm{X}$ & $\mathrm{X}$ & $\mathrm{X}$ & \\
\hline \multicolumn{7}{|c|}{ Audio Visual Diam } \\
\hline $\begin{array}{l}\text { Slow-Scan TV, } \\
\text { Time-Shared TV }\end{array}$ & $\mathrm{X}$ & $\mathrm{X}$ & $\mathrm{X}$ & $\mathrm{X}$ & & TV Diam \\
\hline & $X$ & $\mathrm{X}$ & $\mathrm{X}$ & $\mathrm{X}$ & & $\begin{array}{l}\text { Film } \\
\text { rangkai/Suara }\end{array}$ \\
\hline
\end{tabular}




\begin{tabular}{|c|c|c|c|c|c|c|}
\hline Media Transmisi & 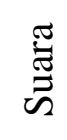 & 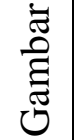 & $\stackrel{\mathscr{E}}{\Xi}$ & 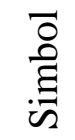 & 范 & $\begin{array}{c}\text { Media } \\
\text { Rekaman }\end{array}$ \\
\hline & $X$ & $X$ & $X$ & $X$ & & $\begin{array}{l}\text { Film } \\
\text { bingkai/suara }\end{array}$ \\
\hline & $\mathrm{X}$ & $\mathrm{X}$ & $\mathrm{X}$ & $\mathrm{X}$ & & Halaman/suara \\
\hline & $X$ & $\mathrm{X}$ & $\mathrm{X}$ & $\mathrm{X}$ & & $\begin{array}{l}\text { Buku dengan } \\
\text { Audio }\end{array}$ \\
\hline \multicolumn{7}{|c|}{ Audio Visual Semi Gerak } \\
\hline \multirow[t]{2}{*}{ Tulisan Jauh } & & & $X$ & $\mathrm{X}$ & $\mathrm{X}$ & $\begin{array}{l}\text { Rekaman } \\
\text { tulisan jauh }\end{array}$ \\
\hline & $\mathrm{X}$ & & $\mathrm{X}$ & $\mathrm{X}$ & $\mathrm{X}$ & Audio pointer \\
\hline \multicolumn{7}{|c|}{ Visual Gerak } \\
\hline & & $\mathrm{X}$ & $\mathrm{X}$ & $\mathrm{X}$ & $\mathrm{X}$ & Film bisu \\
\hline \multicolumn{7}{|c|}{ Visual Diam } \\
\hline \multirow[t]{5}{*}{ Faksimile } & & $\mathrm{X}$ & $\mathrm{X}$ & $\mathrm{X}$ & & Halaman cetak \\
\hline & & & & & & Film rangkai \\
\hline & & & & & & Seri gambar \\
\hline & & & & & & Microform \\
\hline & & & & & & Arsip video \\
\hline \multicolumn{7}{|c|}{ Visual Semi Gerak } \\
\hline Teleautograph & & & $\mathrm{X}$ & $\mathrm{X}$ & $\mathrm{X}$ & \\
\hline \multicolumn{7}{|c|}{ Audio } \\
\hline Telepon Radio & & & $\mathrm{X}$ & $\mathrm{X}$ & $X$ & $\begin{array}{l}\text { Cakram } \\
\text { (piringan) } \\
\text { audio Pita } \\
\text { audio }\end{array}$ \\
\hline \multicolumn{7}{|c|}{ Cetak } \\
\hline Teletip & & & & $\mathrm{X}$ & & Pita berlubang \\
\hline
\end{tabular}

Sumber: Arief S. Sadiman, dkk., 2006

Dari berbagai ragam dan bentuk dari media pengajaran, pengelompokan atas media dan sumber belajar ekonomi dapat juga ditinjau dari jenisnya, yaitu media audio, media visual, media audio-visual, dan media serba neka.

1. media audio: radio, piringan hitam, pita audio, tape recorder dan telepon

2. media visual

a. media visual diam: foto, buku, ensiklopedia, majalah, surat kabar, buku referensi, dan barang hasil cetakan lain, gambar, ilustrasi, kliping, film bingkai, film rangkai, transparansi, mikrofis, overhead proyektor, grafik, bagan, diagram dan sketsa, poster, gambar kartun, peta dan globe

b. media visual gerak: film bisu

3. media audio-visual

a. media audiovisual diam: televisi diam, slide dan suara, film rangkai dan suara, buku dan suara.

b. Media audio visual gerak: video, CD, film rangkai dan suara, televisi, gambar dan suara

4. media serba neka 
a. papan dan display: papan tulis, papan pamer/pengumuman/majalah dinding, papan magnetic, whiteboard, mesin pengganda

b. Media tiga dimensi: realia, sampel, artifact, model, diorama, display

c. media teknik dramatisasi: drama, pantomim, bermain peran, demonstrasi, pawai/karnaval, pedalangan/panggung boneka, simulasi

d. sumber belajar pada masyarakat: kerja lapangan, studi wisata, perkemahan

e. belajar terprogram

f. komputer

\section{E. Pengembangan Media Pembelajaran Berbasis Teknologi Informasi (TI)}

Di era globalisasi dan informasi ini penggunaan media pembelajaran berbasis Teknologi Informasi (TI) menjadi sebuah kebutuhan dan tuntutan namun dalam implementasinya bukanlah merupakan hal yang mudah. Dalam menggunakan media tersebut harus memperhatikan beberapa teknik agar media yang dipergunakan itu dapat dimanfaatkan dengan maksimal dan tidak menyimpang dari tujuan media tersebut.

Arief S. Sadiman, dkk (2006) mengatakan bahwa ditinjau dari kesiapan pengadaannya, media dikelompokkan dalam dua jenis, yaitu media jadi karena merupakan komoditi perdagangan yang terdapat di pasaran luas dalam keadaan siap pakai (media by utilization) dan media rancangan yang perlu dirancang dan dipersiapkan secara khusus untuk maksud dan tujuan pembelajaran tertentu.

Dari pernyataan tersebut di atas dapat dikategorikan bahwa media Komputer dan LCD Proyektor meupakan media rancangan yang di dalam penggunaannya sangat diperlukan perancangan khusus dan didesain sedemikian rupa agar dapat dimanfaatkan. Perangkat keras (hardware) yang difungsikan dalam menginspirasikan media tersebut adalah menggunakan satu unit komputer lengkap yang sudah terkoneksikan dengan LCD Proyektor. Dengan demikian media ini hendaknya menarik perhatian siswa dalam proses pembelajaran.

Teknologi jaringan komputer/internet memberi manfaat bagi pemakainya untuk melakukan komunikasi secara langsung dengan pemakai lainnya. Hal ini dimungkinkan dengan diciptakannya sebuah alat bernama modem. Jaringan komputer/internet memberi kemungkinan bagi pesertanya untuk melakukan komunikasi tertulis dan saling bertukar pikiran tentang kegiatan belajar yang mereka lakukan. Jaringan komputer dapat dirancang sedemikian rupa agar dosen dapat berkomunikasi dengan mahasiswa dan mahasiswa dapat melakukan interaksi belajar dengan mahasiswa yang lain. Interaksi pembelajaran dengan menggunakan jaringan komputer tidak saja dapat dilakukan secara individual, tetapi juga untuk menunjang kegiatan belajar kelompok. Pemanfaatan jaringan komputer dalam sistem pendidikan jarak jauh dikenal juga dengan istilah Computer Conferencing System (CCF). Biasanya sistem ini dilakukan melalui surat elektronik atau E-mail. Beberapa kelebihan pemanfaatan jaringan komputer dalam sistem pendidikan jarak jauh yaitu: dapat memperkaya model-model tutorial, dapat memecahkan masalah belajar yang dihadapi mahasiswa dalam waktu yang lebih singkat dan dapat mengatasi hambatan ruang dan waktu dalam memperoleh informasi. CCF memberi kemungkinan bagi mahasiswa dan dosen untuk melakukan interaksi pembelajaran langsung antar individu, individu dengan kelompok, dan kelompok dengan kelompok (Mason, 1994 dalam Benny A. Pribadi dan Tita Rosita, 2002:13-14)

I Ketut Gede Darma Putra (2009) mengemukakan beberapa media yang dapat digunakan dalam pembelajaran berbasis TI, adalah:

\section{Internet}

Internet adalah media sesungguhnya dalam pendidikan berbasis TI, karena perkembangan internet kemudian muncul model-model e-learning, distance learning, web base learning, dan istilah pendidikan berbasis TI lainnya. Internet merupakan jaringan komputer global yang mempermudah, mempercepat akses dan distribusi 
informasi dan pengetahuan (materi pembelajaran) sehingga materi dalam proses belajar mengajar selalu dapat diperbaharui. Sudah seharusnya dalam penerapan pendidikan berbasis TI tersedia akses internet.

Saat ini wilayah Indonesia yang terjangkau jaringan internet semakin meluas hal ini sebagai dampak dari perkembangan yang pesat dari jaringan telekomunikasi. Mulai dari jaringan telepon rumah/kantor, jaringan Speedy telkom, leased line ISP, sampai dengan komunikasi melalui GPRS, 3G, HSDPA dengan memanfaatkan modem GSM dan CDMA dari provider seluler adalah sederetan teknologi yang dapat digunakan untuk akses internet. Dengan kata lain, saat ini tersedia banyak pilihan teknologi untuk melakukan koneksi pada jaringan global.

\section{Intranet}

Apabila penyediaan infrastruktur internet mengalami suatu hambatan, maka intranet dapat dijadikan alternatif sebagai media pendidikan berbasis TI. Karakteristik intranet hampir sama dengan internet, hanya saja untuk area lokal (dalam suatu kelas, sekolah, gedung, atau antar gedung). Model-model pembelajaran sinkron dan tidak sinkron dapat dengan mudah dan lebih murah dijalankan pada intranet. Menurut penulis, pada kondisi-kondisi tertentu intranet justru dapat menjadi pilihan tepat dalam menerapkan pendidikan berbasis TI.

\section{Mobile Phone}

Pembelajaran berbasis TI juga dapat dilakukan dengan menggunakan media telpon seluler, hal ini dapat dilakukan karena kemajuan teknologi telpon seluler yang pesat. Seseorang bisa mengakses materi pembelajaran, mengikuti pembelajaran melalui telpon seluler. Begitu canggihnya perkembangan teknologi ini sampai memunculkan istilah baru dalam pembelajaran berbasis TI yang disebut M-learning (mobile learning).

\section{CD-ROM/Flash Disk}

Media CD-ROM atau flash disk dapat menjadi pilihan apabila koneksi jaringan internet/intranet tidak tersedia. Materi pembelajaran disimpan dalam media tersebut, kemudian dibuka pada suatu komputer. Pemanfaatan media CD-ROM/flash disk merupakan bentuk pembelajaran berbasis TI yang paling sederhana dan paling murah.

Selain itu I Ketut Gede Darma Putra (2009) Ada 2 komponen utama dalam pembelajaran berbasis TI, yaitu Learning Management System (LMS), dan Learning Content (LC).

\section{Learning Management System}

Ada suatu ungkapan yang menyatakan "if learning content is king, then infrastructure (LMS) is god". Ungkapan tersebut menunjukkan betapa pentingnya komponen LMS dalam pembelajaran berbasis TI. LMS merupakan suatu sistem komputer yang dapat diibaratkan sebagai staff administrasi yang akan mengatur penyelenggaraan proses belajar mengajar. Berikut adalah beberapa fungsi dari LMS:

\section{a. Mengelola materi pembelajaran}

Setiap mata pelajaran akan memiliki materi pembelajaran. Setiap materi pembelajaran akan dikelompokkan berdasarkan kelas (seperti kelas 1, 2, 3) dan juga semester. Pada setiap semester, materi pembelajaran akan dikelompokkan berdasarkan pertemuan pertama, kedua, ketiga, dan seterusnya. Setiap materi pembelajaran kemudian dapat mengalami perubahan atas dasar pergantian kurikulum.

Kondisi di atas akan menjadi rumit ketika kita mencoba untuk menjawab pertanyaanpertanyaan berikut ini:

1) Bagaimana kemudian kalau ada puluhan mata pelajaran dengan ratusan materi pembelajaran?

2) Bagaimana caranya agar peserta (siswa) tidak salah masuk kelas (tidak salah mengambil materi pembelajaran)? 
3) Bagaimana kemudian kalau pengajar ingin menambah atau memperbaiki materi pembelajaran pada suatu semester tertentu?

4) Bagaimana caranya dalam proses belajar mengajar dapat membandingkan materi pembelajaran dari kurikulum yang berbeda atau dari meteri tahun sebelumnya?

5) Dan banyak pertanyaan lainnya yang dapat membuat keadaan dalam proses belajar mengajar berbasis TI menjadi ruwet.

Pertanyaan-pertanyaan ruwet di atas akan menjadi begitu mudah bila proses pembelajaran memiliki LMS. Inilah peran pertama LMS yang mampu mengelola materi pembelajaran dan memandu pengajar dan peserta dalam proses belajar mengajar.

\section{b. Registrasi dan Persetujuan}

LMS dapat melakukan pendaftaran para peserta pembelajaran dan melakukan hal-hal yang bersifat persetujuan apabila ada kondisi yang membutuhkan persetujuan dalam pembelajaran. Fungsi ini juga bermanfaat dalam membatasi mereka yang berhak mengikuti pelajaran dengan mereka yang tidak berhak.

c. Merekam aktifitas belajar mengajar

Peran ketiga dari LMS adalah merekam aktifitas belajar mengajar. Peran ini akan mampu menjawab pertanyaan-pertanyaan seperti: berapa lama, kapan mulai, kapan berakhir proses belajar mengajar (mengakses materi pembelajaran), siapa saja yang hadir, proses diskusi (tanya jawab) yang terjadi, dan memberikan peringatan kepada peserta.

\section{d. Melakukan evaluasi}

Fungsi keempat LMS adalah melakukan evaluasi terhadap proses belajar mengajar menyangkut: mengukur kemajuan peserta antara sebelum melakukan pembelajaran dengan sesudah pembelajaran, mengukur seberapa jauh pemahaman peserta terhadap materi, dan atas dasar hasil evaluasi kemudian memberikan saran ke peserta untuk mengulang kembali beberapa materi pembelajaran yang dianggap kurang. Aspek evaluasi lain yang bisa dilakukan adalah mengukur kepuasan atau persepsi peserta terhadap materi pembelajaran terutama dalam hal penyajian materi. Bagaimanapun ada korelasi yang tinggi antara kemampuan daya serap peserta dengan cara penyajian materi pembelajaran.

\section{e. Media komunikasi}

LMS dapat menjadi media komunikasi, menyampaikan pengumuman, meningkatkan interaktifitas antara pengajar, peserta, dan pihak administrator.

\section{f. Pelaporan}

Muara akhir dari fungsi-fungsi di atas adalah pembuatan pelaporan otomatis dan transparan menyangkut hasil dari proses belajar mengajar. Pembuatan laporan dapat dibuat berdasarkan hak-hak akses dari komponen sekolah. Sebagai contoh pelaporan untuk pimpinan (pihak atasan), pengajar, peserta bahkan mungkin orang tua dapat mengakses dengan fasilitas yang berbeda-beda.

\section{Learning Content}

Learning content adalah materi pembelajaran itu sendiri, yang akan disajikan kepada peserta pembelajaran. Isi materi harus dibuat oleh mereka yang punya kompetensi di bidangnya, tidak peduli apakah mereka memahami banyak tentang TI atau tidak. Setelah isi materi selesai dibuat baru kemudian dibuatkan versi elektroniknya oleh para pengembang content (content developers) sehingga bisa dimasukkan ke LMS.

Penyajian content harus mengandung daya tarik sehingga peserta memiliki minat untuk membaca (mempelajari), mengandung unsur-unsur animasi, suara, video, interaktif, dan simulasi, namun demikian harus tetap memperhatikan bandwidth dari internet atau intranet sehingga tidak terlalu lambat tampil saat dipelajari oleh peserta. Dalam mempelajari materi, peserta harus memiliki kontrol terhadap penyajian materi, dapat melompat dari satu 
topik ke topik yang lainnya. Fasilitas forum, chatting, dan video conference dapat digunakan untuk menjaga interaktivitas.

\section{F. Kesimpulan}

1. Media pembelajaran dapat merupakan wahana penyalur pesan dan informasi belajar. Media pembelajaran yang dirancang secara baik akan sangat membantu peserta didik dalam mencerna dan memahami materi pelajaran. Fungsi media dalam kegiatan pembelajaran bukan sekedar alat peraga bagi guru melainkan sebagai pembawa informasi/pesan pembelajaran. Masing-masing jenis media pembelajaran memiliki karakteristik, kelebihan serta kekurangannya. Itulah sebabnya maka perlu adanya perencanaan yang sistematis untuk penggunaan media pembelajaran.

2. Di era globalisasi dan informasi ini, perkembangan media pembelajaran juga semakin maju. Penggunaan Teknologi Informasi (TI) sebagai media pembelajaran sudah merupakan suatu tuntutan. Walaupun perancangan media berbasis TI memerlukan keahlian khusus, bukan berarti media tersebut dihindari dan ditinggalkan. Media pembelajaran berbasis TI dapat berupa internet, intranet, mobile phone, dan CD Room/Flash Disk. Adapun komponen utamanya meliputi Learning Management System (LMS), dan Learning Content (LC).

3. Penggunaan media pembelajaran ekonomi dapat memperlancar proses pembelajaran dan mengoptimalkan hasil belajar untuk itu sebagai pendidik seyogyanya mampu memilih dan mengembangkan media yang tepat agar proses pembelajaran dapat berjalan lebih efektif dan efisien.

\section{Daftar Pustaka}

Achmad Munib (2004) Pengantar Ilmu Pendidikan. Semarang: UPT MKK UNNES

Arief S. Sadiman, dkk (2006) Media Pendidikan: Pengertian, Pengembangan, dan Pemanfaatannya. Edisi Pertama. Jakarta: PT Raja Grafindo Persada

Depdiknas (2003) Media Pembelajaran. Jakarta : Depdiknas.

Djamarah, Syaiful Bahri dan Aswan Zain, 2002, Strategi Belajar Mengajar, Cetakan Kedua, Jakarta: Rineka Cipta

Heinich, Robert, Michael Molenda, James D. Russel, (1982) Instructional Media: and the New Technology of Instruction, New York: Jonh Wily and Sons.

Hujair AH. Sanaky (2009) Media Pembelajaran. Yogyakarta: Safiria Insania Press

I Ketut Gede Darma Putra (2009) Pendidikan Berbasis Teknologi Informasi. Makalah ini disampaikan pada Rakorda Disdikpora Bali - 10 Maret 2009

Oemar Hamalik (2003) Media Pendidikan, Cetakan VI, Bandung: PT Citra Aditya Bakti Soeparno (1988). Media Pengajaran Bahasa. Jakarta: PT Inter-Pariwisata. 